\title{
Elinikäinen oppiminen ja yksilöivä valta
}

\author{
Elinikäinen oppiminen voidaan nähdä hallintana, \\ joka rohkaisee ihmistä ottamaan vastuun omasta \\ oppimisestaan. Hallinnantutkimusta ja psykoanalyysiä \\ yhdistävä tarkastelu paljastaa, miten elinikäisen oppimisen \\ ideologia ohjaa yksilöä tavoittelemaan aina uusia taitoja \\ yhteiskunnan ja työelämän tarpeiden mukaan.
}

\section{$\boldsymbol{y}$}

ELINIKÄINEN OPPIMINEN ON viimeisen kolmen vuosikymmenen aikana muodostunut keskeiseksi koulutuspoliittiseksi käsitteeksi paitsi OECD:n ja EU:n kaltaisten ylikansallisten poliittisten toimijoiden teksteissä, myös kasvatustieteissä. Käsitteen suosiota selittää jälkiteollinen yhteiskunta, jossa työmarkkinoiden ja työn sisältöjen muutokset ovat yhä nopeampia ja ennakoimattomampia. Vaikka elinikäistä oppimista on mahdotonta määritellä tiiviisti, siinä painottuu usein yksilön koko elämän kestävä ja elämänlaajuinen mahdollisuus oppimiseen ja uudelleenkouluttautumiseen. Elinikäisen oppimisen valmiuksien katsotaan olevan paitsi yksilön elämänlaadun ja työmarkkinakuntoisuuden, myös kokonaisten valtioiden kilpailukyvyn edellytys. (Tuomisto 2012.)

Elinikäisen oppimisen kriittinen analyysi kytkee elinikäisen oppimisen usein niin sanottuun hallintavaltaan. Tämä käsite viittaa siihen, että ihmisiä hallitaan ennen kaikkea vapaina ja vastuullisina yksilöinä. Elinikäisen oppijan hallinta pyrkii välttämään holhoavaa, pakottavaa vallankäyttöä ja olemaan sen sijaan "mahdollistavaa" (enabling). Se rohkaisee ihmisiä kantamaan vastuuta omasta oppimisestaan yhteiskunnan ja työmarkkinoiden nopean muutoksen keskellä. Vallankäyttö on näin ollen yksilöivää. 
Se ulottuu subjektin itseymmärrykseen, niihin yleisiin ehtoihin, joiden kautta ihminen ymmärtää oman itsensä ja vapaan toimintansa päämäärät. Mitä tahansa ihminen halutaan saattaa tekemään, on olennaista, että hän voi tunnistaa siinä oman autonomiansa ja intressiensä toteutumisen. (Fejes \& Nicoll 2008.)

Hallintavallan tarkastelu elinikäisen oppimisen alueella nojaa Michel Foucault'n 1970-luvun tuotannossaan esittämiin käsityksiin yhteiskunnallisesta vallankäytöstä (Fejes \& Nicoll 2008). Yhteiskuntatieteissä on tänä päivänä lähes mahdotonta analysoida vallankäyttöä viittaamatta foucault'laisiin käsitteisiin ${ }^{1}$. Brittiläinen, erityisesti Nikolas Rosen, Peter Millerin ja Mitchell Deanin tunnetuksi tekemä hallintavallan analyysi on vuosituhannen vaihteen jälkeen nostanut elinikäisen oppimisen vallankäytöstä esiin aiemmin vähälle huomiolle jääneitä piirteitä, kuten yksilön autonomian ja itseymmärryksen hallinnan. Analyysissä ei kuitenkaan ole käsitelty sitä, miten yksilö sisäistää tämän vallankäytön, ja mitkä ovat ne subjektissa vaikuttavat voimat, jotka voivat tehdä elinikäisestä oppimisesta yksilötasolla vaikuttavia.

Tämä artikkeli esittää vaihtoehtoisen tavan käsitteellistää sitä, miten valta ulottuu yksilön itseymmärrykseen elinikäisessä oppimisessa. Hyödynnän parin viime vuosikymmenen aikana uuteen suosioon noussutta tapaa yhdistää psykoanalyyttisiä teorioita ja käsitteitä ideologiakritiikkiin. Tukeudun tässä erityisesti Slavoj Žižekin sekä Žižekin tuotantoa tulkitsevan Todd McGowanin ajatteluun.

Tarkoitukseni ei ole tehdä elinikäisen oppimisen vallankäyttöä koskevaa empiiristä tutkimusta psykoanalyyttisin välinein. En myöskään esitä yksityiskohtaista teoreettista analyysiä Žižekin psykoanalyyttisistä käsitteistä. Sen sijaan osoitan, miten psykoanalyyttistä näkökulmaa hyödyntämällä voi kuvata elinikäisen oppimisen hallinnan sisäistymistä subjektin toimintaa motivoivaksi itseymmärrykseksi.

Tarkastelen aluksi lyhyesti hallintavallan analyysin keskeisiä piirteitä suhteessa elinikäiseen oppimiseen. Kuvaan erityisesti, miten elinikäisessä oppimisessa pyritään saattamaan vallankäyttö itseymmärryksen tasolle. Tämän jälkeen esittelen psykoanalyyttisen halun käsitteen, jolla kuvaan vallan sisäistymistä uhrauksen logiikkana ja halun kaksoissidoksena.

\section{HALLINTAVALTA JA ELINIKÄINEN OPPIMINEN}

Hallintavallan tutkimuksessa on osoitettu, että nykyinen, laajalle levinnyt uusliberalistinen hallinta korostaa yhteiskunnallisten rakenteiden sijaan vapaita ja autonomisia yksilöitä. Tähän liittyy myös normatiivinen oletus: yksilöiden ei tule jättää itseään ulkopuolisten tahojen holhottavaksi, vaan ottaa vastuu omasta elämästään. (Foucault 2008, 215-239.) Koulutuspolitiikassa tämä on näkynyt pyrkimyksenä "vapauttaa” koulutus keskitetystä valtiollisesta kontrollista markkinoiksi, joissa jokainen yksilö saa vapaasti valita itselleen sopivia koulutuspalveluita. Koulutusjärjestelmät nähdään tällöin dynaamisina ja itseään säätelevinä, sillä ne karsivat itsestään tarpeettomat ja huonosti toimivat palvelut. (Ball \& Olmedo 2013.)

Vapaiden, autonomisten yksilöiden kuvasto on ollut 1990- ja 2000-lukujen aikana havaittavissa myös elinikäisen oppimisen strategioissa. Tämä ilmenee esimerkiksi OECD:n ja EU:n koulutuspoliittisissa dokumenteissa. Koulutuksen yhteiskunnallisten rakenteiden sijasta niissä painotetaan yksilön oppimista, hänen itsenäisiä valintojaan sekä vastuutaan omasta menestyksestään (Fejes 2008; Lambeir 2005).

Yksilöivä, autonomiaa ja vastuuta korostava hallinta ilmenee myös käytäntöinä, joissa ihmisiä rohkaistaan omaksumaan elinikäisen oppijan identiteetti ja tunnustamaan se muille. Ihmisiä ohjataan tarkastelemaan ja arvioimaan itseään elinikäisen oppimisen kriteerien valossa. (Edwards 2008; Fejes \& Dahlstedt 2013.)

Juuri tämä yksilötasolle ulottuva "vallan mikrofysiikka” on nähty olennaisena hallintavallan analyysissä. Hallintavallan legitiimiyden kannalta on tärkeää mahdollistaa yksilön vapaa ja vastuullinen toiminta. Näin ollen yksilön itseymmärrykseen vaikuttavista käytännöistä tulee välitysmekanismi, jonka kautta hallintavalta vaikuttaa. Näiden strategioiden ja käytäntöjen tarkoituksena on toteuttaa "hallintaa etäältä” (Rose 1999, 49-50). Siinä ylhälltä alas suuntautuva ja pikkutarkka valta on minimoitu. Samalla valta kuitenkin tunkeutuu entistä vahvemmin ihmisen itseymmärrykseen; siihen miten hän tunnistaa itsensä yritteliäänä ja vastuullisena yksilönä. (Mt.; Miller \& 
Rose 2010, 32.) Tämä ei ole alistavaa ja passivoivaa valtaa, vaan, kuten Peter Miller ja Nikolas Rose (2010,214) toteavat:

"kysymys on yksilöiden saamista uusista kyvyistä, valmiuksista ja ominaisuuksista. Ja nämä uudet ominaisuudet voidaan vuorostaan välittää muille niin, että syntyy eräänlainen 'kerrannaisvaikutus'. Aina kun ideoita ja tekniikoita välitetään, syntyy lisäarvoa."

Elinikäisessä oppimisessa vaikuttaa myös tämänkaltainen horisontaalinen valta, jossa ihmiset rohkaisevat toinen toisiaan voimaantumaan itsehallinnan ja vapauden nimissä (Edwards 2008, 26; Wain 2015, 197). Valtaa on tällöin vaikeampi jäljittää, koska olemme näennäisesti oman itsemme ja elinikäisen oppimisemme asiantuntijoita (Fejes 2008).

Yllä kuvattu elinikäisen oppimisen hallinnan tutkimus ei ole ideologiakritiikkiä, sillä sen pohjalta ei voi tehdä jakoa oikeaan ja väärään tietoisuuteen. Hallintavallan analyysissä kaikkia objektiivisen tiedon ja rationaalisuuden muotoja tarkastellaan paikallisesti, historiallisesti määräytyneiden diskurssien ja käytäntöjen seurauksina. (Miller \& Rose 2010.)

Hallintavallan analyysin ulkopuolelle on myös jäänyt se, miten ihminen voi ylipäätään haluta identifioitua yrittäjämäiseksi yksilöksi ja miten hän voi pitää kyseistä identiteettiä velvoittavana (Jones \& Spicer 2005, 224). Tämä voidaan nähdä foucault'laisesta ontologiasta juontuvaksi.

Foucault ei olettanut diskurssien ja hallinnan käytäntöjen taustalle mitään universaalia subjektia, jonka sisäisyyttä ja psyykkisiä mekanismeja olisi mahdollista tarkastella (Foucault 2005, 254). Esimerkiksi vapauden ja hallinnan jännite ilmaistaan siten, että subjektin on sisäistettävä tietyt itsen käytännöt voidakseen tunnistaa ja hallita itseään vapaana yksilönä (Foucault 1998; Miller \& Rose 2010, 11). Subjekti on tässä pelkkä "laskos". Hallinnan päämäärät on "taitettu” tai "laskostettu” itsen käytäntöjen kautta subjektin sisäisyydeksi ja itsehallinnaksi. (Dean 1996; Webb \& Gulson 2013.) Judith Butlerin (1997, 84-87) ja Slavoj Žižekin (2000, 296-305) kaltaiset yhteiskuntateoreetikot ovat huomauttaneet, että vallan analyysistä jää tällöin jotakin olennaista kysymät- tä: mikä on se substanssi, johon hallinnan käytännöt tukeutuvat, ja jonka myötä ulkoisista hallinnan tekniikoista tulee sisäisiä (ks. myös Copjec 1994, 6-7, 17-18)? Tähän kysymykseen vastaamattomuutta ei tarvitse nähdä hallintavallan analyysin erheellisyytenä, sillä sen lähtökohdista nämä eivät ole lainkaan relevantteja kysymyksiä.

Psykoanalyyttinen teoriaperinne, johon Butler ja Žižek'kin tukeutuvat, voi kuitenkin avata uusia näköaloja myös siihen, miten elinikäisen oppimisen hallinta "kutsuu" (Butler 1997, 95) subjektia itsen käytännöissä. Näen, että vallan sisäistymisessä on tällöin otettava huomioon halu sekä halua koskevien kieltojen ja käskyjen psykodynamiikka (ks. myös Copjec 1994, 24-25; McGowan 2004).

\section{HALUN KÄSITE LACANILAISESSA PSYKOANALYYTTISESSÄ TEORIASSA}

Psykoanalyysin ja yhteiskuntateorian yhdistämisessä ei ole mitään uutta. Jo psykoanalyysin perustaja Sigmund Freud ulotti maalailevassa ja filosofisessa esseessään Ahdistava kulttuurimme (1972) psykoanalyyttiset käsitteet koskemaan koko yhteiskuntaa. Sittemmin psykoanalyysi on tarjonnut jatkuvasti virikkeitä erityisesti kriittiselle yhteiskuntateorialle ja sen tavalle käsitteellistää ideologiaa. ${ }^{2}$ Ihminen ei psykoanalyyttisessä teoriaperinteessä ole ainoastaan tietoinen olento, vaan hänen toimintaansa ohjaavat myös tiedostamattomat yllykkeet. Yhteiskunnallinen ideologia vaikuttaa tavoilla, joista subjekti ei itse ole lainkaan tietoinen. (Frosh 1999.)

Slavoj Žižek (s. 1949) on ajankohtaisia politiikan ja kulttuurin ilmiöitä aktiivisesti kommentoiva slovenialainen yhteiskuntateoreetikko ja filosofi. Hän yhdistää teksteissään erityisesti lacanilaista psykoanalyysiä, hegeliläistä filosofiaa sekä marxilaista yhteiskuntakritiikkiä. Žižekin edustamassa niin sanotussa lacanilaisessa psykoanalyyttisessä traditiossa subjekti ei ole objektivoitavissa persoonaksi, identiteetiksi tai toimijuudeksi. Sen sijaan subjektilla viitataan diskursseissa ilmenevään jatkuvaan subjektivoitumisen prosessiin. (Parker 2011, 13.) ${ }^{3}$

Lacanilaisessa traditiossa subjekti viittaa myös ikuiseen puutteeseen tai keskeneräisyyteen (Žižek 
2005; Žižek 2000, 306-307; Fink 1995). Puute saa lacanilaisessa traditiossa monenlaisia tulkintoja. Viittaan sillä tässä yhteydessä kuviteltuun menetykseen tai uhraukseen subjektivoitumisen prosesseissa. McGowanin (2013, 28-29) arvoituksellisen muotoilun mukaan subjekti on olemassa sen traumaattisen kokemuksen kautta, jossa hän uhraa yhä uudelleen sen, mitä hänellä ei koskaan ollutkaan. Tämä "kadotettu objekti” on eräänlainen jäänne psyykkisestä syntymästä, jonka myötä subjekti voi kuvitella olevansa erillinen ja itsenäinen olento. Samalla subjekti menettää välittömän yhteyden vanhempaansa tarpeiden tyydyttäjänä ja turvan tuojana. (Žižek 1997, 18-19.) Tarkalleen ottaen subjekti ei kuitenkaan uhraa tai menetä mitään, sillä subjektia ei varsinaisesti ole edes olemassa ennen psyykkistä irtautumista vanhemmasta. Menetys on siis takautuvasti asetettu illuusio. (Fink 1995, 93-94.)

Kuviteltu menetys ei jää pelkästään lapsuuden ainutlaatuiseksi tapahtumaksi, vaan se määrittää ihmisen olemassaoloa. Kuvitellun kadottamisen kautta syntyy subjektin toimintaa ylläpitävä halu. Subjekti voi siis olla vain haluavana, ja halu voi olla olemassa ainoastaan kuvitellun uhrauksen kautta (McGowan 2004, 2013).

Samalla kun menettäminen on eräänlainen illuusio, myöskään halun kohdetta, niin sanottua "halun objekti-syytä" tai "objekti a:ta", ei varsinaisesti ole olemassa. Jos ihminen saavuttaisikin haluamansa, esimerkiksi unelmiensa työpaikan, se lakkaisi pian olemasta haluttu asia, ja halu siirtyisi jälleen uusiin kohteisiin (Žižek 2006, 66-68; 2005, 139-140; McGowan 2013, 69). Toisin kuin biologinen tarve (kuten nälkä), halu ei etsi tyydytystä, vaan pyrkii aina säilymään, lisääntymään ja liikkumaan (Fink 1995, 90-91).

Halu ei sijaitse yksiselitteisesti subjektin sisä- tai ulkopuolella. Ihmisen psykologista kehitystä ohjaa “toisen halu” eli se mitä toiset ihmiset häneltä haluavat. Psyyken kehityksessä tämä liittyy aluksi vanhempien lapselle välittämiin käskyihin, toiveisiin ja vihjeisiin, mutta yleistyy myöhemmin koskemaan koko yhteiskuntaa. Subjektin muotoutumista ohjaa näin reagointi toisen oletettuihin haluihin. Subjekti pyrkii selvittämään, mitä toinen häneltä haluaa, ja olemaan itse toisen halun kohde. Toisen halusta syntyy näin subjektin oma halu. Vaikka subjekti on halun kautta liitetty ympäröivään yhteiskuntaan, hän ei kuitenkaan ole sen sätkynukke. Subjektia määrittää myös kyky reflektoida toisen halua ja ottaa siihen etäisyyttä; kysyä olenko todella se mitä minulta halutaan ja haluanko itse toteuttaa toisen halua. (Žižek 1997,7-10; 2005, 160-164.)

Uhraus, jossa erillinen ja haluava subjekti muotoutuu, on myös ihmisen sosialisaation ehto. "Normaaliksi” aikuiseksi subjektiksi kasvetaan eräänlaisen “isän kiellon” kautta (Žižek 2000, 172-175; McGowan 2013, 103-104). Isän kielto on vertauskuvallinen ilmaisu eriytymättömyyden ja välittömän nautinnon kokemisen mahdottomuudelle. Näin isän kielto suojelee psyykeä, sillä yhteys nautintoon vailla etäisyyttä tai erillisyyttä olisi sietämätöntä ja psyyken kannalta tuhoisaa. Tämä kielto tai este on paitsi ehkäisevä ja suojeleva, myös tuottava, sillä se ohjaa subjektin halua yleisesti hyväksyttyihin muotoihin. Näin ollen yhteiskunta perustuu halun koordinoinnille, eli sitä voi ohjata eri toimijoille hyödyllisiin suuntiin. (McGowan 2004; Mura 2015, 160-161.)

Välittömän nautinnon kokemisen kieltävät lait ja normit tekevät mahdolliseksi myös kapinan ja tottelemattomuuden, sillä ilman kieltoa ei ole myöskään kiellon rikkomista. Esimerkiksi koulutuksen ja työelämän instituutioissa kieltojen olemassaolo on mahdollistanut avoimen kapinoinnin opettajan tai työnjohtajan auktoriteettia vastaan, sekä kyvyn nauttia salaisten rikkeiden tekemisestä. (Vrt. Žižek 2002; 2006, 83-85.)

Yhteenvetona voidaan todeta, että psykoanalyyttisessä kuvauksessa foucault'lainen tiedon subjekti (subjekti tiedon kohteena ja subjekti, joka tuntee itsensä) korvautuu halun subjektilla (Copjec 1994, 24-25). Ihminen ei toimi ainoastaan sen pohjalta mitä hän tietää, vaan myös sen ohjaamana miten hän haluaa (McGowan 2013, 16). Tämä lähtökohta muuttaa näkökulmaa elinikäisen oppimisen vallankäyttöön ja sen tapaan kohdistua subjektiin.

Elinikäinen oppiminen toimii yksilöivän vallan kautta, rajaamalla tapoja, joilla ihminen voi tunnistaa itsensä vapaana ja autonomisena yksilönä. Kuvaan seuraavaksi, miten elinikäisen oppimisen ideologia kiinnittyy subjektia konstituoivaan haluun ja siihen liittyvään uhraamisen logiikkaan. Siinä halu ohjataan 
elinikäisen oppimisen diskurssien ja käytäntöjen alueelle. Tämä tapahtuu antamalla uhraukselle symbolinen ilmaus, eli esittämällä jotakin yksilön kannalta tärkeää menetetyksi. Samalla osoitetaan, että vain elinikäisen oppimisen käytäntöjen kautta hän voi saada haluamansa.

\section{UHRAAMISEN LOGIIKKA}

\section{ELINIKÄISEN OPPIMISEN IDEOLOGIASSA}

Žižekin mukaan fantasia uhratusta eheydestä ja mahdollisuudesta saavuttaa se tulevaisuudessa määrittää paitsi subjektin halua, myös ideologioita, joissa kuvataan yhteiskunnallisia muutoksia. Esimerkiksi laajalti omaksutut tarinat yhteiskuntien modernisaatiosta tarjoavat kuvan kokonaisesta ja autenttisesta kokemuksesta, jonka yhteiskunnan rationalisoituminen ja sen eri funktioiden eriytyminen on tuhonnut, mutta joka voidaan palauttaa. Uhrauksen logiikka tarjoaa siis mittapuun, jonka kautta kollektiivisen tason menettämistä ja saavuttamista voi arvioida. (Žižek 1997, 14-17.)

Tämä näkyy myös elinikäisen oppimisen ideologian tavassa kuvata yhteiskunnan muutoksia ja niiden merkitystä yksilölle. Esimerkiksi OECD (2007) toteaa, että työelämässä yksilön elämää kehystävät rakenteet ovat viimeisen kolmen vuosikymmenen aikana muuttuneet radikaalisti. Opitut taidot vanhentuvat jälkiteollisessa yhteiskunnassa nopeasti. Tämä pakottaa päivittämään niitä jatkuvasti. Vanhat ammatit katoavat uusien tieltä samalla kun turvatuista ja pysyvistä työpaikoista tulee entistä harvinaisempia (mt.).

Näiden muutosten tuloksena yksilön elämänkaari ei enää koostu selkeistä vaiheista, joissa koulutuksella ja oppimisella on oma paikkansa. Sen sijaan elämänkaari on pirstaloitunut koulutuksen, työn ja työttömyyden toisiaan ennakoimattomasti seuraaviin osiin. Elinikäisen oppimisen ideologia luo mielikuvia jatkuvasta uudelleenkouluttautumisen tarpeesta. Sen myötä ihminen näyttäytyy pysyvänä vajeena suhteessa työmarkkinoiden vaatimuksiin. Tämän vajeen korjaamiseksi elinikäisen oppimisen valmiudet ovat olemassa. Koska ei voida tietää, mitä taitoja huomisen yhteiskunnassa tarvitaan, elinikäinen oppiminen panostaa yleisiin valmiuksiin ja metataitoihin, kuten oppimaan oppimiseen. (Edwards 2008, 31-32; Jokisaari 2004, 9-10.)
Tämä johtaa subjektin kysymään jatkuvasti, mitä minulta halutaan. Mitä minulta puuttuu, jotta voisin vastata minuun kohdistuviin vaatimuksiin? Elinikäinen oppiminen pureutuu näin tiukasti subjektin perustaviin halun prosesseihin. Tämä kadotetun objektin (objekti a:n) etsintä on aina tuomittu epäonnistumaan, sillä ihminen uhraa yhä uudestaan sen, mitä hänellä ei koskaan ollutkaan, ja jota hän ei voi koskaan saada. Tietojen ja taitojen pääoma lakkaa siis nopeasti olemasta haluttu "se" ja kiihdyttää halun kohteen etsimistä. Lisäksi oppiminen esitetään paitsi elinikäisenä, myös elämänlaajuisena: se ei enää ole rajattu koulutusinstituutioiden seinien sisään tai työelämään, vaan se voi tapahtua missä tahansa (Edwards 2008; Tuomisto 2012, 420-421, 433).

Oppimisella ei myöskään ole tänä päivänä olemassa mitään erityistä sisältöä. Siksi lähes mistä tahansa osaamisesta voi tulla tulevaisuuden hyödyllistä kompetenssia. Subjektia houkutellaan olemaan sitoutumatta mihinkään erityiseen ammattiin tai osaamiseen. Hallintavallan analyysi on osoittanut, miten tämä oppimisen rannattomuus johtaa jatkuvaan itsen mobilisointiin, jossa yksilö ja hänen valmiutensa ovat jatkuvassa muutoksessa (Simons \& Masschelein 2008, 55).

Edellä esitetystä psykoanalyyttisestä näkökulmasta elinikäisen oppimisen on perustuttava jatkuvaan halun mobilisaatioon, jossa halun on liikuttava nopeasti ja ohjatusti yhä uusiin kohteisiin. Näin halu ajaa elinikäisen oppijan tuotannon ja kulutuksen kiihkeästi toimivaan kehään: koulutustuotteiden aikaansaama osaamispääoma kulutetaan nopeasti työmarkkinoilla, mikä johtaa jälleen uusien oppimishyödykkeiden kulutukseen (vrt. Jokisaari 2004, 12). Elinikäinen oppija on asemassa, jossa hän ei voi koskaan varmasti tietää, miltä se mitä häneltä puuttuu ja mitä häneltä halutaan, voi tulevaisuudessa näyttää, ja mistä sitä voi etsiä.

Renata Saleclin (2003) mukaan kapitalistinen yhteiskunta perustuu tähän ikuisen puutteen kultivointiin tuottamalla jatkuvasti ongelmaa, jota se pyrkii samalla korjaamaan. Se tuottaa ahdistusta, sillä subjekti ei koskaan varmasti tiedä, mitä häneltä vaaditaan, sekä syyllisyyttä siitä, ettei hän kykene vastaamaan yhteiskunnan vaatimuksiin. Samalla kapitalistinen yhteiskunta kuitenkin tarjoaa erilaisia itsensä kehittämisen käytäntöjä näiden oireiden lääkitsemiseen. (Mt.) 
Elinikäisen oppimisen ideologia perustuu siis ikuisen uhrauksen kultivoinnille. Se antaa symbolisen ilmaisun puutteelle ja kanavoi näin ihmisen halua. Se väittää ilmaisevansa sen, mitä ihmiseltä puuttuu, ja mitä hänen täytyy tehdä saavuttaakseen haluamansa. Samalla se asettaa halun alituiseen liikkeeseen yli koulutuksen ja työelämän vanhojen institutionaalisten rajojen. Elinikäisen oppimisen ideologia jättää paljastamatta sen dialektisen luonteen: se pitää auki juuri sitä haavaa, jota se pyrkii lääkitsemään. Samalla kun ideologia antaa lupauksen objekti a:n saavuttamisesta, on sen samalla pidettävä halun kohteet etäällä.

\section{HALUN KAKSOISSIDOS}

Miksi ihminen sitten ei kokisi elinikäisen oppimisen ideologiaa pelkästään ulkoa asetettuina vaatimuksina, joilla ei ole mitään tekemistä hänen todellisen vapautensa ja autenttisen minuutensa kanssa? Elinikäisessä oppimisessa yksilöitä hallitaan usein vapauden kautta: houkuttelemalla subjekti ymmärtämään oman autonomiansa ja omien tavoitteidensa toteutuminen vallitsevissa elinikäisen oppimisen käytännöissä. Žižek (1997, 27-29) puolestaan toteaa ideologian toimivan voimakkaimmillaan juuri silloin, kun subjekti kieltää olevansa ideologian ohjaama, ja sen sijaan autenttinen, yksilöllinen ihminen. Myös elinikäinen oppiminen toimii varmimmin silloin, kun se saa otteen subjektin halusta toteuttaa itseään ja omimpia toiveitaan.

Viimeaikaisissa psykoanalyyttisen ja kriittisen teorian yhdistävissä keskusteluissa on osoitettu, miten halun ohjaaminen toimii myös autenttisuutta ja autonomiaa korostavan retoriikan avulla. Slavoj Žižekin mukaan nykyisestä, liberaalista ja kulutuskeskeisestä yhteiskunnasta on näennäisesti kadonnut kieltävä isähahmo (Žižek, 1997; 2000, 338, 399; Copjec 1994, 182). Nyky-yhteiskunta korostaa vanhojen kieltojen ja rajoitusten katoamista. "Sinä voit!" on tämän kulttuurin motto (Žižek 1999; 2006, 37; vrt. Salecl 2010).

Kulutuskeskeinen yhteiskunta luo kuvitelman, jonka mukaan ihminen voi saavuttaa kaiken haluamansa luopumatta mistään (Mura 2015, 161-163). Žižekin mukaan nyky-yhteiskunnassa vallitseva nau-

\section{ELINIKÄISEN OPPIMISEN}

IDEOLOGIA LUO

MIELIKUVIA JATKUVASTA

UUDELLEENKOULUT-

TAUTUMISEN TARPEESTA.

tinnon korostaminen johtaa uudenlaiseen "hedonistiseen askeesiin”. Tämä viittaa itsekontrollin ja kehittämisen käytäntöihin, jotka eivät enää perustu kieltäymykselle, vaan mielihyvän välittömälle kokemiselle. (Žižek 2006, 28; Mura 2015, 158.)

McGowanin mukaan työelämän hallinta perustui vielä 1900-luvun alussa ideologiaan, jossa työntekijän on uhrattava vapauttaan, aikaansa ja energiaansa työlle, jotta hän voisi myöhemmin nauttia vapaaajastaan haluamallaan tavalla (McGowan 2004, 31, 33-34). 1900-luvun jälkipuoliskolla sen sijaan erityisesti humanistiseen psykologiaan pohjautuvissa johtamisopeissa alettiin korostaa mahdollisuutta nauttia itse työstä, sekä nähdä siinä välttämättömän taakan sijaan oman vapauden ja toiveiden toteutuminen. Tämä ideologia alkoi korostaa myös hierarkkisten valtasuhteiden katoamista (McGowan 2004, 34; vrt. Boltanski \& Chiapello 2005).

McGowanin mukaan näyttääkin siltä, että monilla työpaikoilla sen koommin kuin koulussakaan ei enää ole käskeviä tai kieltäviä auktoriteetteja, vaan samassa veneessä olevia innostajia ja fasilitaattoreita. Siinä missä esimies tai opettaja oli ennen etäinen ja autoritäärinen, on hän uudessa työn ja oppimisen ideologiassa jopa sietämättömän lähellä. Samalla kun hän korostaa tasavertaisuutta ja dialogisuutta, hän lietsoo ja tarkkailee herkeämättä yksilön motivaatiota ja innostusta. (McGowan 2004; vrt. Miller \& Rose 2010.)

Nämä näkökulmat eivät välttämättä koske yhteiskuntaa ja elinikäistä oppimista kokonaisuudessaan. Psykoanalyyttinen tulkinta niistä kuitenkin osoittaa uhrauksen logiikan rinnalla kulkevan tavan ohjata halua vapauden ja mielihyvän nimissä. Elinikäisessä 
oppimisessa voidaan löytää vahvasti emansipatorinen eetos, joka julistaa yksilön mahdollisuutta toimia koulutuksen kentällä vapaasti, ilman pakkoa ja itseään toteuttaen (Lambeir 2005).

Vaikka taustalla onkin huoli taloudellisesta kilpailukyvystä, elinikäisen oppimisen ideologiassa korostetaan usein oppimisen iloa, intohimoa ja innostavuutta (Edwards 2008; vrt. Tuomisto 2012, 422). Samalla yksilöitä houkutellaan tutkimaan itseään ja löytämään sisäsyntyinen halu oppia, sekä tunnustamaan se muille (Edwards 2008, 26-31). Elinikäisen oppimisen ideologiassa luodaan siis kuvitelma, jonka mukaan oppimisessa ei enää ole kyse pelkästään lopputuloksesta, jonka hedelmistä yksilö voi uhrauksen kautta nauttia tuonnempana. Sen sijaan oppiminen on myös prosessi, josta yksilö voi kokea välitöntä tyydytystä.

Tämänkaltainen elinikäisen oppimisen ideologia ilmenee esimerkiksi työvoimapoliittisessa koulutuksessa. Siinä työnhakijalle tehdään työllistymissuunnitelma, jossa hän oppii hakemaan itsenäisesti ja aktiivisesti työtä tai koulutuspaikkoja. Yksilöllisten työllistymis- ja opintosuunnitelmien sekä haastattelujen yhteydessä yksilöä houkutellaan tunnistamaan ja tunnustamaan julkisesti oma, autenttinen motivaationsa ja tulevaisuudensuunnitelmansa ulkoa märïteltyjen ennakkoehtojen mukaisesti. (Fogde 2008.) Humanistisen psykologian retoriikan tavoin ohjauksessa korostuu "holistinen" ymmärrys ihmisen potentiaalista. Ulkoa tapahtuvan pakottamisen sijaan korostetaan, että ihmisen sallitaan tehdä omia, itsenäisiä koulutus- ja uravalintoja. Aivan kuin ohjauksessa ei olisi lainkaan kyse vallankäytöstä, vaan ainoastaan jo olemassa olevien yksilön kykyjen "vapauttamisesta”. (Mt.; Fejes \& Dahlstedt 2013, 59-60.)

Elinikäisen oppimisen ideologia määrittää halun koordinaatteja. Edellä kuvatun kadotetun objektin (objekti a:n) paikalle subjekti voi projisoida omien voimavarojensa vapautumisen vailla ulkoisia esteitä ja kieltoja. Ennakoimattomien työmarkkinoiden vaatimukset voivat siis tulla vaikuttaviksi, ei ainoastaan pelon ja häpeän välttämisen kautta, vaan myös siten, että ihminen saatetaan näkemään elinikäinen oppiminen eräänlaisena emansipaationa ja oman mielihyvän rajoittamattomana lisääntymisenä.
Ideologiat, joissa aiemmin kielletty nautinto on nyt kaikkien ulottuvilla, kuitenkin peittävät syvemmän tason ideologisia rakenteita (Žižek 1997, 25-26). Kiellot ja käskyt eivät näet suinkaan ole kadonneet tämänkaltaisen ideologian hallitsemasta yhteiskunnasta. Isän kielto ja käskevä yliminä ovat edelleen olemassa. Ne ovat vain vaikeammin tiedostettavissa, sillä ne piiloutuvat kaksoissidoksen, eli ristiriitaisen viestinnän taakse.

Yhtäältä ideologia viestii, että ihmisen toiminnan tulisi (kieltojen ja alistamisen aikakauden jälkeen) perustua vapaalle tahdolle ja sille, mikä ihmistä aidosti motivoi. Toisaalta ideologia sisältää julkilausumattoman kiellon. On selvää, ettei autenttisuus voi olla mitä tahansa, se ei voi olla passiivisuutta, kieltäytymistä oppimisesta. Yksilölle siis tarjotaan vapaus, jonka säilyttäksseen hänen on pakko alistua tietynlaisiin vapauden muotoihin. (Žižek 1997, 3538.) Samalla kun tämä ideologia kieltää käskemisen olemassaolon, se sisältää entistä ankaramman, vaikkakin tiedostamattoman, käskyn motivoitua, olla innostunut ja aktiivinen. (Žižek 1999; McGowan 2004; 2013, 102-103.)

Tämä näkyy esimerkiksi Leenamaija Otalan (2002) elinikäisen oppimisen oppaassa. Yhtäältä Otala painottaa, että elinikäinen oppiminen on nyky-yhteiskunnassa sekä yrityksille että yksilöille välttämättömyys. Toisaalta hän korostaa, että elinikäinen oppiminen tarjoaa valinnan: ihminen voi niin halutessaan nauttia oppimisesta ja jatkuvasta itsensä kehittämisestä. Ihminen voi tehdä elinikäisestä oppimisesta eräänlaisen taitolajin, jossa hän voi täydellistyä saavuttaen samalla kilpailuetua muihin yksilöihin tai yrityksiin nähden. (Mt.) Näin luodaan illuusio siitä, että ihminen voi tulla itseriittoiseksi ja riippumattomaksi muista. Keskeistä muutoksissa selviytymiselle on ihmisen kyky innostua ja motivoitua. Tällaisessa ihmiskuvassa ei ole tilaa tarvitsevuudelle eikä sisäisen hämmennyksen tai ahdistuksen ilmaisuille. (Vrt. Žižek 2000, 472-474.)

Nautintoon kehottavaa käskyä vastaan on vaikeampaa kapinoida kuin etäistä ja avoimesti käskevää auktoriteettia. Elinikäisen oppimisen ideologiassa käsky innostua ei tule ulkoa ja ylhäältä päin, vaan toverillisena rohkaisuna, joka houkuttelee subjektin 
“aidot potentiaalit” esille. Samalla kuitenkin (McGowan 2004) juuri haluamisesta ja mielihyvän kokemisesta on tullut hankalaa. Edellä kuvatusta halun luonteesta näet seuraa, että mikäli halun kohde on aina välittömästi käsillä, haluamisesta tulee mahdotonta. Ilman kadotettua objektia elämältä on vaikeaa löytää tyydytystä (McGowan 2013, 13, 90, 113).

Žižekin mukaan sosiaalisesta todellisuudesta onkin tullut kesytettyä. Siinä ei ole mitään käsittämätöntä, vaarallista tai uhkaavaa, eikä toisaalta myöskään etäistä, kiehtovaa ja todellista mielihyvää tuottavaa. Vallitseva ideologia lupaa, että subjekti voi saada kaiken aiemmin kielletyn, kunhan halun kohteesta on poistettu sen vaarallinen ja ennakoimaton sisältö. Ihminen voi esimerkiksi nauttia työssään innovatiivisesta toiminnasta, mutta ainoastaan, mikäli innovatiivisuus on kesytettyä ja huolellisesti kanavoitua. (Žižek 2006, 38; Salecl 2010.)

Välitöntä mielihyvää korostava ideologia voi johtaa myös siihen, että elinikäisestä oppimisesta tulee omantunnon kysymys. Mikäli ihminen sisäistää elinikäisen oppimisen käskyn innostua ja iloita oppimisesta, hän tuntee huonoa omaatuntoa: ei enää ulkoisen auktoriteetin kiellon rikkomisesta (joka olisi helpompi käsitellä), vaan siitä, ettei hän motivoidu uudelleenkouluttautumiseen tai loppumattomaan työnhakuun. Hän ei siis onnistu seuraamaan yliminän käskyä (vrt. Žižek 2006). Olli-Jukka Jokisaari (2004), tosin toisenlaisesta teoreettisesta näkökulmasta, on todennut, että ikuinen syyllisyys on keskeinen osatekijä elinikäisen oppimisen subjektin hallinnassa.

Psykoanalyyttisen teorian pohjalta voidaan todeta, että syyllisyys ja riittämättömyyden kokemus eivät ole tarkoituksellisesti tuotettuja, vaan edellä mainitun kaksoissidoksen sivutuotteita. Syyllisyys ja riittämättömyys eivät myöskään kumpua ainoastaan siitä, että ihminen ei onnistu saamaan haluamaansa. Ne saavat voimaa myös siitä, ettei ihminen kykene haluamaan tavalla, johon elinikäinen oppiminen häntä houkuttelee (vrt. Salecl 2010). Kuten halua, myöskään yliminän käskyä ei voida koskaan tyydyttää. Kaikki pyrkimykset olla yritteliäs ja motivoitunut vain ruokkivat ankaraa käskyä innostua oppimisestä vielä enemmän (vrt. Žižek 2006).

\section{LOPUKSI}

Hallintavallan analyysin lähtökohtia muotoillut Michel Foucault näki modernin yhteiskunnallisen vallankäytön toimivan uhkaamisen ja avoimen väkivallan sijasta viettelemällä ja suostuttelemalla. Sen sijaan, että se korostaisi vallankäyttäjän roolia, hallintavalta tekee näkyväksi vallan kohteen yksilönä ja kohdistuu hänen itseymmärrykseensä. Elinikäisen oppimisen voi katsoa edustavan juuri tämänkaltaista yksilön vapauden kautta toteutuvaa hallintaa. Kriittinen analyysi kohdistuu tällöin niihin diskursseihin ja itsen muokkaamisen käytäntöihin, joiden kautta rajataan elinikäisen oppijan kykyä tunnistaa itsensä vapaana yksilönä sekä kanavoidaan sitä hallinnan tavoitteiden mukaisesti. Kritiikki pyrkii myös horjuttamaan näiden diskurssien sisältämiä totuuksia ja avaamaan tilan olla vapaa ja yksilöllinen jollakin toisella, ennalta määräämättömällä tavalla.

Psykoanalyyttinen elinikäisen oppimisen ideologian tarkastelu puolestaan kysyy, miten yhteiskunnallinen vallankäyttö sisäistyy osaksi subjektin itseymmärrystä ja millä tavoin se motivoi subjektin toimintaa ja ajattelua. Samalla se avaa halun dynamiikan tutkimuksen kohteeksi.

Olen tässä artikkelissa käsitteellistänyt kaksi tapaa, joilla yksilöivä hallinta koordinoi halua. Ensinnäkin se toimii uhrauksen logiikan kautta, jossa elinikäisen oppimisen käytännöt paikkaavat näennäisesti subjektissa olevan puutteen. Toinen tapa on tarjota kaksoissidos, jonka mukaan subjekti on vapaa ja samalla velvoitettu innostumaan elinikäisestä oppimisesta kaiken aikaa. Näin ollen se, että löydän oman "autenttisen minäni" elinikäisestä oppimisesta, tarkoittaa sitä, että oma haluni on jo ohjattu ulkoapäin. Psykoanalyyttisesti orientoituneen aikuiskasvatuksen kriittisen tutkimuksen tehtävä onkin osoittaa yksilölle tapa, jolla ideologia ohjaa halua, ja samalla avata mahdollisuus haluta autonomisella tavalla. (Vrt. Žižek 2006, 39.)

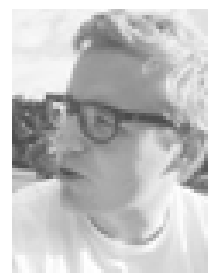

Antti Saari

$K T$, tutkijatohtori

Kasvatustieteiden yksikkö

Tampereen yliopisto 
Baker, B. (2007). Normalizing Foucault? A rhizomatic approach to plateaus in anglophone educational research. Foucault studies 4, 78-119.

Ball, S. J., \& Olmedo, A. (2013). Care of the self, resistance and subjectivity under neoliberal governmentalities. Critical Studies in Education 54(1), 85-96.

Boltanski, L., \& Chiapello, E. (2005). The new spirit of capitalism. International Journal of Politics, Culture, and Society 18(3-4), 161-188.

Butler, J. (1997). The Psychic Life of Power. Stanford: Stanford University Press.

Copjec, J. (1994). Read my desire. Lacan against the historicists. Cambridge (Mass.) MIT Press.

Dean, M. (1996). Foucault, government, and the enfolding of authority. Teoksessa A. Barry, T. Osborne \& N. Rose (toim.) Foucault and Political Reason.Chicago: University of Chicago Press, 209230.

Edwards, R. (2008). Actively seeking subjects? Teoksessa Fejes, A. \& Nicoll, K. (toim.) Foucault and Lifelong Learning: Governing the Subject. London: Routledge, 21-33.

Fejes, A. (2008). To be one's own confessor: educational guidance and governmentality. British Journal of sociology of education, 29(6), 653-664.

Fejes, A., \& Dahlstedt, M. (2013). The confessing society: Foucault, confession and practices of lifelong learning. London: Routledge.

Fejes, A. \& Nicoll, K. (2008). Mobilizing Foucault in studies of lifelong learning. Teoksessa Fejes, A. \& Nicoll, K. (toim.) Foucault and Lifelong Learning: Governing the Subject. London: Routledge, 1-18.

Fink, B. (1995). The Lacanian Subject: Between Language and Jouissance. Princeton: Princeton University Press.

Fogde, M. (2008). Self-governance in the job search: regulative guidelines in job-seeking. Teoksessa Fejes, A. \& Nicoll, K. (toim.) Foucault and Lifelong Learning: Governing the Subject. London: Routledge, 103-113.

Foucault, M. (1998). Seksuaalisuuden historia. Helsinki: Gaudeamus. [kirjan nimi kursiivilla]

Foucault, M. (2005). Tiedon arkeologia. Tampere: Vastapaino.

Foucault, M. (2008). The Birth of Biopolitics: Lectures at the Collège de France 1978-1979. New York: Palgrave Macmillan.

Freud, S. (1972). Ahdistava kulttuurimme. Jyväskylä: Weilin+Göös.

Frosh, S. (1999). The Politics of Psychoanalysis: An Introduction to Freudian and post-Freudian Theory, 2nd ed. London: Macmillan.
Frosh, S. (2003). Psychosocial studies and psychology: Is a critical approach emerging? Human Relations 56(12), 1545-1567.

Helén, I. (2010). Hyvinvointi, vapaus ja elämän politiikka: Foucault'lainen hallinnan analytiikka. Teoksessa J. Kaisto \& M. Pyykkönen (toim.) Hallintavalta. Helsinki: Gaudeamus, 27-48.

Johnston, A. (2014). Jacques Lacan. Teoksessa Zalta, E.N. (toim.) The Stanford Encyclopedia of Philosophy. http://plato.stanford.edu/archives/sum2014/entries/ lacan/

Jokisaari, O.J. (2004). Elinikäinen oppiminen - häpeä ja menetetty vapaus. Aikuiskasvatus 24(1), 4-16.

Jones, C., \& Spicer, A. (2005). The sublime object of entrepreneurship. Organization 12(2), 223-246.

Lambeir, B. (2005). Education as liberation: The politics and techniques of lifelong learning. Educational Philosophy and Theory 37(3), 349-355.

McGowan, T. (2004). The End of Dissatisfaction. Jacques Lacan and the Emerging Society of Enjoyment. Albany: SUNY Press.

McGowan, T. (2013). Enjoying What We Don't Have: The Political Project of Psychoanalysis. Lincoln: University of Nebraska Press.

Miller, P. \& Rose, N. (2010). Miten meitä hallitaan. Tampere: Vastapaino.

Mura, A. (2015). Lacan and debt. Philosophy Today 59(2), 155-174.

OECD (2007). Qualifications Systems: Bridges to Lifelong Learning. Paris: OECD Publishing.

Otala, L. (2002). Oppimisen etu: Kilpailukykyä muutoksessa. Helsinki: WSOY.

Parker, I. (2011). Lacanian Psychoanalysis: Revolutions in Subjectivity. London: Routledge.

Rose, N. (1999). Powers of Freedom: Reframing Political Thought. Cambridge: Cambridge University Press.

Salecl, R. (2003). Success in failure, or how hypercapitalism relies on people's Feeling of Inadequancy. Parallax 9(2), 96-108.

Salecl, R. (2010). Self in times of tyranny of choice. FKWIIZeitschrift für Geschlechterforschung und visuelle Kultur 48(50), 10-23.

Simons, M. \& Masschelein, J. (2008). Our 'will to learn' and the assemblage of a learning apparatus. Teoksessa Fejes, A. \& Nicoll, K. (toim.) Foucault and Lifelong Learning: Governing the Subject. London: Routledge, 48-60.

Tuomisto, J. (2012). Elinikäinen oppiminen: oikeus vai pakko? Teoksessa Kettunen, P. \& Simola H. (toim.) Tiedon ja osaamisen Suomi. Helsinki: SKS, 411-435. 
Wain, K. (2015). Lifelong learning and making the self. Teoksessa A. Fejes ja K. Nicoll (toim.) Foucault and a Politics of Confession in Education. London: Routledge. 191-203.

Webb, P. T., \& Gulson, K. N. (2013). Policy intensions and the folds of the self. Educational theory 63(1), 51-68.

Žižek, S. (1997). The Plague of Fantasies. London: Verso.

Žižek, S. (1999). You may! London Review of Books 21(6), 3-6.

Žižek, S. (2000). The Ticklish Subject: The Absent Core of Political Ontology. London: Verso.

Žižek, S. (2005). Ideologian ylevä objekti. Vantaa: Apeiron.

Žižek, S. (2006). How to Read Lacan. London: Granta.

1 Ilpo Helénin (2010) mukaan Foucault onkin nykyajan Marx; niin monille eri yhteiskunnan alueille hänen tunnetuksi tekemiään käsitteitä on sovellettu. Bernadette Baker (2007) puolestaan toteaa, että Foucault'n ajattelu on englanninkielisen kasvatustieteen piirissä 1990-luvulta saakka normalisoitu keskeisten käsitteiden ja tutkimusstrategioiden käytöksi.

2 1900-luvulla erityisesti Herbert Marcuse ja Erich Fromm ovat yhdistäneet psykoanalyyttistä teoriaa marxilaiseen yhteiskuntakritiikkiin. Viime vuosikymmeninä muun muassa Stephen Frosh (2003) ja lan Parker (2011) ovat yhdistäneet psykoanalyyttisiä näkökulmia kriittiseen sosiaalipsykologiaan.

3 Lacanin subjektia määrittävä käsitteistö on psykoanalyyttisessä traditiossa varsin omintakeinen ja vaikeaselkoinen. Lacanilaisen teorian yleisesittelyissä subjekti on usein esitetty kolmen toisiinsa kietoutuvan rekisterin, imaginaarisen, symbolisen ja reaalisen, kautta (ks. esim. Johnston 2014). Näiden rekisterien esittely ei kuitenkaan ole tämän artikkelin puitteissa mahdollista. 